\title{
IMAGENS DE MINHA MÃE: RELATOS E EXPERIÊNCIAS DE GÊNERO ÚTERO-FILIAL
}

\author{
Maryori Katherine Cabrita GARCIA \\ Ana Cláudia do Amaral LEÃO
}

\begin{abstract}
RESUMO
O presente ensaio narrativo-fotográfico se aproxima de uma experiência de gênero em que o relato da autora sobre sua mãe e avó, visibiliza a violência de gênero avó-mãe-filha, tríade social e (re) produtiva útero-filial. Busca-se refletir sobre o arquétipo da mãe dominada, as feminidades magoadas e as rejeições da infância como herança das feridas sociais. Tal relato é proposto a partir do imaginário de histórias vividas no sistema patriarcal do contexto andino-venezuelano. Além das experiências relatadas, as imagens fotográficas exercitam um olhar reflexivo sobre a arte de viver e a prática artística que se restaura nos afetos, no amor e na sororidade entre mulheres. Utilizou-se na trama metodológica: o arquétipo da Órfã e a Deusa Suja da psicóloga Clarissa Pinkola Estés; a experiência de gênero da psicóloga Maria Elisa Cabral e a relação do nu fotográfico como um olhar intersubjetivo da feminidade.
\end{abstract}

Palavras-chave: Experiência de Gênero; Violência; Mãe; Arquétipo; Fotografia de Nu.

\section{IMAGES OF MY MOTHER: REPORTS AND EXPERIENCES OF UTERUS-BRANCH GENRE}

\begin{abstract}
The present narrative-photographic essay approaches a genre experience in which the author's report on her mother and grandmother makes gender-grandmother-daughter violence, social triad and (re) productive utero-filial. It seeks to reflect on the archetype of the dominated mother, the hurtful feminities and the rejections of childhood as inheritance of social wounds. This account is proposed from the imaginary of stories lived in the patriarchal system of the Andean-Venezuelan context. In addition to the experiences reported, the photographic images exercise a reflective look on the art of living and the artistic practice that is restored in affection, love and sorority among women. It was used in the methodological plot: the archetype of the Orphan and the Dirty Goddess of the psychologist Clarissa Pinkola Estés; the genre experience of the psychologist Maria Elisa Cabral and the relationship of the photographic nude as an intersubjective look at femininity.
\end{abstract}

Keywords: Gender Experience; Violence; Mom; Archetype; Photo of Nude.

\section{IMAGGENES DE MI MADRE: RELATOS Y EXPERIENCIAS DE GÉNERO ÚTERO-FILIAL}

\section{RESUMEN}

El presente ensayo narrativo-fotográfico, se acerca a una experiencia de género donde el relato de la autora sobre su mamá y abuela visibiliza la violencia de género abuela-madrehija; triada social e (re)productiva útero-filial. Se busca reflexionar sobre el arquetipo de la madre dominada, las feminidades deprimidas y los rechazos de la infancia como herencia de las heridas sociales. Este relato plantea a partir del imaginario de historias vividas en el sistema patriarcal del contexto andino-venezolano. Además de las experiencias, las imágenes fotográficas experimentan una mirada reflexiva sobre el arte de vivir y vivir y la práctica artística que se restaura en los afectos, el amor y la sororidad entre mujeres. Se utilizó en la trama metodológica: el arquetipo de la huérfana y la Diosa Sucia de la psicóloga Clarissa Pinkola Estés; la experiencia de género de la psicóloga María Elisa Cabral y la relación del desnudo fotográfico como el mirar intersubjetivo de la feminidad.

Palabras clave: Experiencia de Género; Violencia; Madre; Arquetipo; Fotografía de Desnudo.

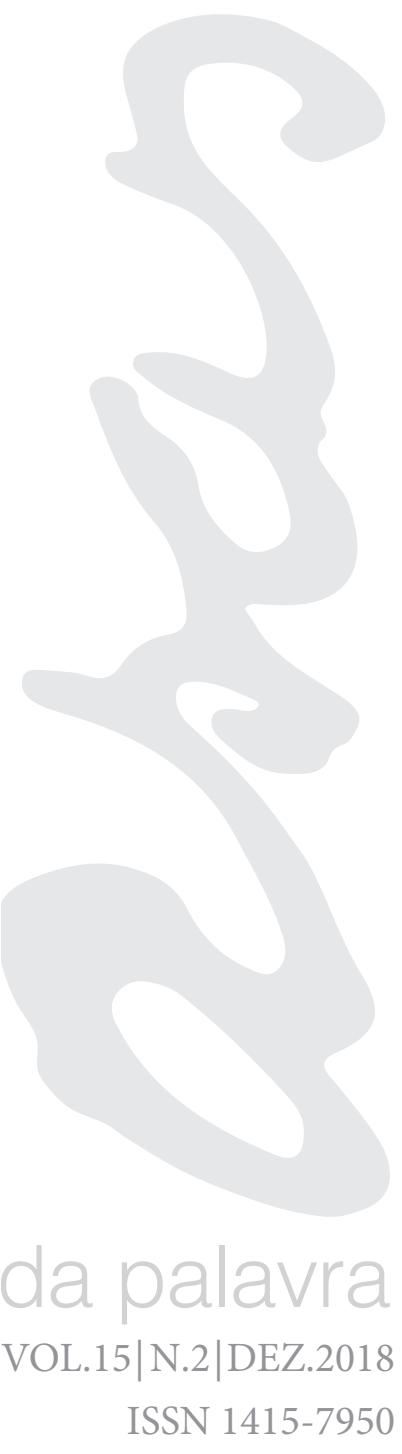




\section{A MÃe MÚLTiPLA}

As fotografias e relatos presentes neste ensaio são imagens que nasceram da escuta sensível entre nós (minha mãe e eu), que abriram as memórias de nossas intersubjetividades, as quais estavam imersas no lar e, em nossas histórias mais próximas, com o intuito de fazer uma travessia necessária, submergir-nos nas águas primordiais, e nos sanar do "self-básico da psique que é ferido desde cedo" (ESTÉS, 2014, p. 200). Seguindo a ideia lacaniana, conscientizei de meu devir histórico-cultural- familiar no estágio do espelho de minha mãe, em que ali, a partir desse rosto, e nesse corpo, refletiu a sua história. É o imaginário de minha mãe interior, como cópia latente da mãe e da avó verdadeira, com os mesmos valores e ideias sobre o mundo, ali, onde minha infância foi construída como sujeito e objeto sexual do patriarcado, e de onde preciso refletir e olhar-me na desconstrução das nossas feminidades magoadas.

...Ir ao encontro da subjetividade, epistemologicamente sugere outro
jeito de abordar-se (o superar-se?) da dicotomia antiga sujeito-objeto;
é entanto, a reconstrução do devir no tempo e na memória das verda-
deiras protagonistas, nas especificidades dos processos, nos entreveros
da experiencia de vida de Si e do Outro, em seus modos de relação, dos
aconteceres da sua própria realidade, e ademais onde uma encontra-se
espelhada e até surpresa ao que está na frente de nós ao se reconhecer
que existe a vida que se escuta em outras histórias... (CABRAL, 2013,
p. 497)

Aqui em Belém do Pará sempre chove! Hoje, a chuva está cheia de saudade. Saudade da criança, aquela que brincava na chuva, toda molhada, no quintal da avó Ida, há muito tempo, lá nas terras andinas venezuelanas; onde nasce o imaginário feminino-familiar e nosso elo umbilical: vó, mãe, eu.

Hoje, enquanto escrevo, penso nelas, em especial na minha mãe; sua mensagem que chegou ao celular, ontem. Quis saber se tudo estava bem comigo, se estou me alimentando nas horas certas, se as coisas no mestrado estão fluindo, se necessita saber alguma coisa mais dela e da nossa família.

Ela sempre pensa em mim, em meu bem-estar. Talvez seja o que acontece com a maioria das mães, não é? Eu só procuro entendê-la, no gesto de maior aproximação, pois a vida não tem sido fácil para nós.

Agora, sei o que é a saudade, quando estamos longe das pessoas que amamos. Vem as lembranças do que fomos, do que agora somos, a arte de viver no reencontro, a arte de me lembrar como mulheres presentes, lutadoras e Deusas.

$\mathrm{E}$, assim aparecem as imagens que quis esquecer - ocultas na psique, no corpo dos tempos vividos com ela, do lar que costuramos há muito tempo, no vaivém das lutas pela sobrevivência, nos rastros de um inesquecível mundo patriarcal que nos odeia.

Está claro que sou sua única filha, sua única família - já que minha avó riscou o céu! No entanto ela, na sua ausência, a tem presente no cotidiano, como uma imagem inesquecível de amor. Minha mãe nos tem como seus grandes amores. Penso nesse amor, no amor da mãe incondicional, há séculos ensinado e vivenciado em brincadeiras de casinha e bonecas. A cultura patriarcal dominante é letal. No seu modo mais simples desgasta a energia de nossa ecologia vital, de nosso imaginário feminino-familiar, quando nos faz crer e viver imaginando-nos mães em tenra idade, quando nos faz pensar somente desse jeito, somente para casar, para reproduzir. Onde está uma outra procriação para nossas vidas? Minha mãe, vivendo nesse amor incondicional, tem o temor de me perder, ficar sozinha o resto da vida sem mim, sua única razão de vida.

Ela sempre me diz: - Quando for mãe, aí você vai ver a ligação de uma 
possuem essa plena intuição cósmica, nascida com a gestação e o cordão umbilical de seu bebê. É um sistema de comunicação único e intrauterino o que acontece entre ambos; é a conexão com uma energia imanente, uma força animal, alimentada de emoções, cheiros, gostos, sensações múltiplas; ajudando-as a criar outras percepções e compartilhamentos com a vida e o amor.

Há uma conexão inconsciente, criação da arte de viver entre dois, um (com) partilhar de mudanças que vão interligando-se. Um processo de gestação que se encarna em ambos, mas, esse Outro Ser alimenta-se dos cuidados da mulher que, descorporificando-se, surge para além da mãe. Diante dela, vai-se perdendo parte da identidade anterior. Aceitar a gravidez é a imanência da imagem-Mãe, transformada dentro dela e fora dela, e talvez parecida com as lembranças da sua mãe da infância. Desse modo, segue sentindo-se, às vezes, irreconhecível frente a seus olhos: enxerga-se entre o antes e o depois de grávida, e continua crescendo com a outra sujeita (o), sua filha (o), e entre idas e vindas tenta ser a mãe boa, a mãe que não quer ser, a mãe possível, a que alguma vez sonhou ser...

Ainda que a memória antiga da fertilidade, da criatividade, da gravidez esteja mascarada e edulcorada nas Nossas Senhoras, existem múltiplas Marias judaico-cristãs, ocultas em outras imagens. Trata-se da imanência que atravessa nossos antigos imaginários e rituais das Grandes Deusa Mães, espalhadas pelo mundo inteiro que contam a história da humanidade diferentemente da história de Maria. Maria foi inconscientemente camuflada como resistência uterina, como mulher, outrora senhora de seu corpo, sua sexualidade e do sistema (re)produtivo. Percebemos isso ao olhar a história da arte e a sua estatuária ancestral. Existimos nessas outras múltiplas mães: a Catal Huyuk, a Venus von Willendorf, a Hator, a Mut, a Issis, a Anunaki, a Durga, a Gaia, a Kwuan Yin, Gea-Zemé, Papatuanuku, a Iemanjá, etc. E, na América Latina estão: a Pachamama, Tlazolteotlem, Chalchiuhtilcue, dentre outras. Na Venezuela, está a Vênus da Tacarigua e a protetora de minha mãe: a Maria Lionza.

\section{A MUDANÇA INEVITÁVEL}

Quanto menos preocupada estivesse minha mãe, mais tranquila eu ficaria! Sei de sua solidão agora. Assim, ficou depois do falecimento inesperado de meu padrasto. Nem eu, nem ela, esperávamos que ele deixasse esta vida tão de repente. Quinze anos compartilhados em família, acabaramse num dia!

A última vez que falamos com ele, era cedo, pela manhã. Ele ainda na cama, falou-nos por telefone: - estou me sentindo mal, vou à casa da minha mãe - a senhora América, sua mãe havia morrido de câncer em 2010, creio. Eu estava em aulas e minha mãe trabalhando. Nem lhe passou pela cabeça, que em poucas horas a coisa ficaria pior. Ao meio-dia, do dia 9 de maio de 2017, meu pai morreu no quarto de sua mãe, no Barrio Urbina, em Caracas.

Um tio dele nos explicou: - Enders, estava conosco, inclusive havia tomado café de manhã com seu pai e, de repente quando estavam no quarto de sua mãe, caiu no chão! Chamamos a ambulância, eles chegaram logo e o levaram! Mas no caminho, já era tarde demais, o coração dele deixou de bater! Os médicos nos confirmaram que ele havia tido um infarto fulminante.

A morte é assim: inesperada, intempestiva, arrasa tudo o que foi planejado, muda à vida toda! Depois de sua morte, a vida de Marisela (minha mãe) mudou ainda mais. Seu companheiro, por quinze anos, deixou de pertencer ao nosso mundo, a nossa família, ao nosso cotidiano. 


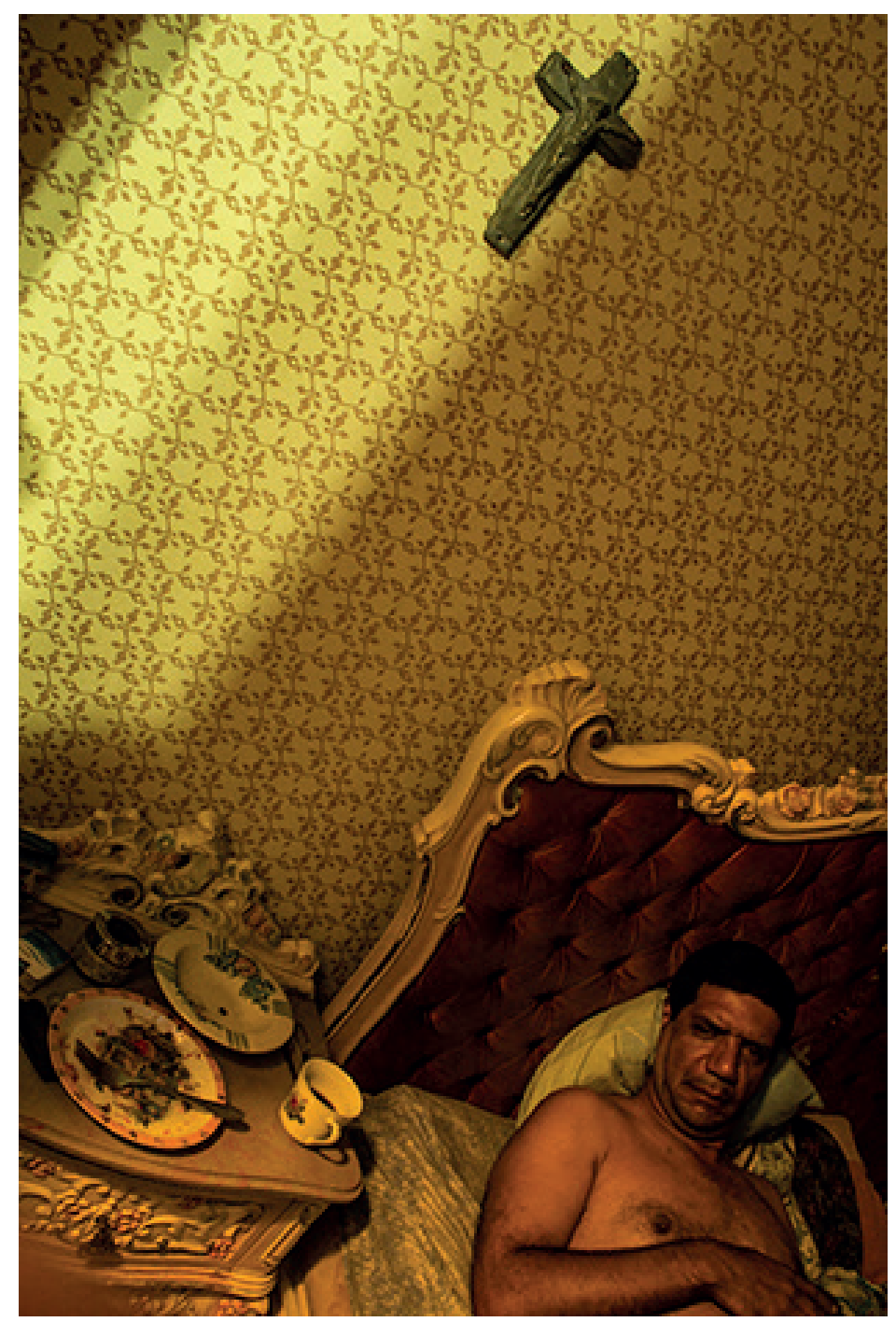

Figura $n^{\circ} 1$

De todos os ex-namorados ou companheiros de minha mamãe, ele era o segundo pai que eu havia aceitado. Eu o quis muito, de verdade! Ainda sinto sua falta. Vi nele o amor por minha mãe. Por isso escolhi fotografá-lo; acolher sua imagem para não esquecê-lo ou compensar sua ausência nessa fotografia. (Figura $\mathrm{n}^{\circ} 1$ )

Depois do funeral, procurarmos rir, mamãe e eu, das ocorrências de papai. Sempre lembraremos com amor o tempo em que vivemos junto a ele, e arquivar as memórias boas perto de nós! Dali a um mês, eu já iria ao Brasil, estudar mestrado em Artes na Universidade Federal do Pará. Naquele momento, era nosso tempo para rirmos juntas. Penso que na verdade, foram muitas mudanças para minha mãe em tão pouco tempo. Entretanto, a vida é assim. É inevitável não mudar, ainda que não queiramos, nem percebemos que as mudanças estão sempre em curso. E, meus planos de viagem estavam prontos, e ela, sabia disso!

Minha mãe me ensinou a lutar desde criança, a fazer da arte minha vida; mas quando a sinto presa a mim, este sentimento me produz profunda tristeza, às vezes. Quero vê-la libertar-se em seu ritmo, em sua vontade, com voz própria, sem esperar que eu volte. Ela ainda é tão jovem, tem amor para dar e dar-se, tem a arte de viver e se reconstruir.

Espero que seu luto seja passageiro. Aprimoro esse sentimento em 
como certa vez ouvi alguém dizer sobre ela. Dessa maneira a conheci desde criança: rápida, audaz, valente, dinâmica, perspicaz, aguda, bruxa, intuitiva, inventora, aventureira, ousada. É dessa mulher que fiz múltiplas fotografias, nua em nosso lar.

Além disso, a contradição de sua vida está nas experiências que ela teve com os homens, as quais, infelizmente, jamais foram muito boas. $\mathrm{Na}$ verdade, muitas foram ruins e lhe deixaram marcas de tristeza: pesadas pedras no coração e dores, ao longo de suas relações com o amor, a vida, a sexualidade e a confiança com os outros.

\section{O IMAGINÁRIO ÚTERO-FILIAL NA CRIANÇA REJEITADA}

Antes de ela nascer, em 24 de maio de 1965, em Trujillo, terra andina venezuelana, Marisela (Figuras $n^{\circ} 2$ e n⿳3 3 ) sentiu o abandono de seu pai (Pablo Emidio), só pelo fato de nascer e de se lembrar da minha avó Ida: mulher magra, de pele argila avermelhada pelo sol, cabelos de seda preto e compridos, até as nádegas, de cara pequena e olhos azuis - celeste que maravilhavam as pessoas.

Minha avó havia decidido não cumprir as obrigações conjugais. Numa época em que as tradições do bom comportamento sustentavamse na moral judaico-cristã e ainda na aplicação, por exemplo, do Manual do Carreño, livro publicado no ano 1853. De origem mexicana, o manual percorreu todas as casas latino-americanas e sul-americanas desde o século XIX até o século XX e estabeleceu-se como instrumento pedagógico de contenção dos corpos e suas pulsões, legitimando a ideologia cristã sobre a importância de se comportar de determinado jeito nos lugares públicos e "privados": como o lar, a família, a escola, o trabalho. O livro contém lições e conselhos sobre o dever das mulheres à obediência ao marido, à família e a dedicação aos filhos, bem como o controle de suas pulsões e desejos.

Então, como castigo a sua desobediência, o jeito que meu avô Pablo Emídio encontrou para descarregar seu ódio por seu comportamento, foi não ajudá-la mais na manutenção de seus onze filhos e filhas. Além disso, não reconheceu a filha mais jovem (minha mãe), manchando sua honra diante do olhar punitivo e cultural da sociedade andina-venezuelana da época. Ainda não satisfeito com tais atitudes, fez do lar o tormento cotidiano de minha mãe, ao fazê-la beber sua amarga negligência, lançando-lhe sempre um olhar enregelante, ignorando-a até a sua morte.

Por isso, desde criança, quando olhava nos olhos de minha mãe e de minha avó, uma tristeza profunda me ligava àquelas expressões. Nem percebia que nossos olhares eram parecidos, que representavam a ausência dos pais. Eram todas expressões carregadas de melancolia, como se alguma coisa perdida permanecesse no curso da vida; em nossos olhos acolhíamos o apanhador de sonhos, para afastar as tristezas da Órfã.

\section{AS MÁSCARAS DO AMOR QUE FERE}

Uma noite, depois de jantar e sentadas na sala da casa, perguntei à mamãe por meu avô Pablo Emídio, e ela me falou primeiro do perdão; então, contou-me: - Eu sonhei com ele um dia quando tu ainda estavas no meu útero, ele já havia morrido faz tempo. Naquele sonho ele pediu que eu o perdoasse por tudo, por sua negligência e crueldade, e foi o que fiz: Eu o perdoei naquele portal. Quando acordei, pela primeira vez senti teu avô perto de mim, ou talvez fosse isso o que eu ansiava ter; sei lá. Ele realmente enfim estava me protegendo nesse caminho tão difícil que era estar sozinha, adolescente, mãe solteira e ainda rejeitada por teu pai e vovó ida, filha! Eu sabia que meu pai, foi um homem que cometeu muitos erros na vida, porque foi educado assim, para ser severo no lar. Naquele tempo, entre os 
anos sessenta até quase os oitenta, lá, na Valera, as mulheres de meu povo deveriam permanecer caladas, fazer as coisas do lar e principalmente aceitar as ordens do pai ou esposo. Mas, filha, que eu podia fazer? Era uma menina, a vida antes era assim, com esses costumes. Ainda com as mulheres já tendo conquistado o direito ao voto em 1946, no interior da Venezuela, a maioria não tinha ensino, não sabia ler, nem escrever! O direito das mulheres e das crianças de terem uma vida livre de violência era algo desconhecida, por um simples fato: a ignorância nos governava diariamente. Por isso, aceito que assim era meu pai, o fato irreversivel dessa sociedade, e o que eu podia fazer por mim, para melhorar minha vida e a vida que agora acolhia meu útero, era me despir dele, procurar sair da dor que ele me causou para seguir adiante. Assim, daquele sonho deixei, enfim o peso do passado de meu pai. Estava livre, pelo menos da imagem de ódio dele!

Essas intimidades - reveladas por minha mãe - representam o imaginário simbólico das experiências primordiais que tem sido a história social e política de meu país, e, também a construção da memória da vida de nossa feminidade familiar, pois minha avó Ida, contou-me que foi abandonada por sua mãe e pai, e educada por seus avós, que a tratavam com violência por muitos anos; antes de casar-se, já desesperada, com Pablo Emidio (meu avô). Erro, que só olharia depois, quando com o tempo ele também começou a violentá-la. Minha avó não me contou muitos detalhes sobre essa violência; só me deixou uma coisa clara; aos 15 anos, uma vez, estávamos no quintal:

- Neta, estude muito e seja independente, porque os homens não estão nem aí para nós ajudar, a maioria é ruim, só pensam que as mulheres existem para lhes abrir as pernas e satisfazer seus desejos, sem se importar se querem ou não. Eles simplesmente usam a força e seu poder para nos magoar.

Entendi tempos depois aquelas conversas surgidas na intimidade do lar, sobre a lógica da política erótica do sistema patriarcal, porque como elas, eu também fui rejeitada por meu pai, que repetiu a receita social, castigou-me pela ousadia de minha mãe por não aceitar mais que continuasse brincando com o corpo e o amor dela; e mais: minha mãe não aceitou deixar-me com meus avós paternos.

A memória familiar foi tecendo na repetição das crianças abandonadas por seus pais. A imanência das órfãs, enfrentando a situação de se sentirem lutando sozinhas no mundo, procurando o amor, e enfrentando a realidade das perdas, tão latente no contexto venezuelano: a primeira violência simbólica é reproduzida e cimentada em paternidades irresponsáveis. Fazse, na construção social, política e econômica da existência de uma infância vulnerada continuamente pelo Estado e pela família.

Contudo, olhamos com naturalidade a perda dos Direitos Humanos fundamentais nas populações mais pobres, levando-nos a acreditar que o bem viver é algo que pertence aos contos de fada. Historicamente, o aumento do abandono infantil se intensifica com as mães solteiras e adolescentes, que igualmente são rejeitadas pela sociedade, pela família, pelo homem porque pertencem ao mesmo fenômeno social, econômico e político do patriarcado que as vitimizam duas vezes: uma simplesmente por nascer e a outra por se reproduzir da mesma forma, gerando um ciclo de desamparo histórico no qual a infância, saúde, maternidade e sexualidade não são objetos de cuidado. A realidade das políticas públicas não é repensada em seus aspectos culturais, sociológicos e psicológicos desde a ação emancipatória e descolonial. Sendo assim, restam os altos índices de violência presentes no cotidiano que impactam a ecologia dos corpos, as sexualidades e as histórias sociais e familiares.

O sistema machista coloca em primeiro lugar as mães adolescentes, como futuras vítimas. Nesse processo, são as primeiras consideradas culpadas, por serem mulheres é claro, e ainda pior, por serem pobres! A história nos dá até hoje, a certeza de que como sujeitas, construídas sexual e historicamente, VOL. $15 \mid$ N.2 | DEZ.2018 a maioria de nós, engravida em tenra idade e se assume no lar, sozinhas e 
rejeitadas, com suas filhas (os) nos braços; aspectos de um processo sociocultural letal, que vai magoando os corpos, suas sensibilidades, sua psique, seu amor próprio; parte de um conjunto de informações, transferível de geração a geração. O sigilo da herança está ali, espalhado em nossos imaginários intrauterinos, corporais, individuais e coletivos.

A memória das mulheres está vinculada ao movimento e ciclo uterinos, repete o que lhe foi dado como passado histórico e cultural constituído, deixando-nos sinais do que tem sido constelado como cosmogonia de amor e dor. Sei que amar é o maior sentimento que todos aprimorarmos na vida. Nascemos e queremos nos sentir amados, vivemos querendo amar e amar ao(s) outro(s), queremos nos apaixonar, sentir cócegas no ar. A poética do amor está misturada à experiência, à compreensão, aos afetos saudáveis, às aprendizagens, com a certeza de quem constrói vida em conjunto, para nos melhorar como seres humanos e fazer-nos sentir livres e felizes. Entretanto, nós mulheres ainda estamos cegas. Nossa visão ainda está nublada porque olhamos para o amor, mediado pelo patriarcado há muito tempo.

Somos ainda o "Outro constituído como simples objeto, sexualizado na intenção erótica de um sujeito, o ato já é a alienação do outro como simples mediação de autoerotismo" (DUSSEL, 2013, p. 57). Esse sujeito privilegiado a que faz referência, o autor foi na imagética do corpo feminino associado à satisfação dos homens, à poética da imagem do amor nas mulheres. Foi o alvo para se idealizar como trágico- homérico, na conquista do corpo da mulher e as crianças como butim de guerra, como coisa para se ganhar, escravizar-se, vender-se, para se comprar, como telenovelas e contos de fadas, de príncipes e princesas, de mulheres pobres encontrando homens ricos, da mulher virgem entregando-se à dádiva da experiência do homem esperto, etc. Também nos ensinaram a sentir e a ver uma prática amorosa não consensual, a deixar sangue na cama, no chão! Os agressores do patriarcado se escondem por trás de máscaras e personagens para ocultar em nossas sociedades o ódio à mulher.

Minha mãe, por exemplo, foi uma mulher que procurou nos homens a proteção que jamais encontrou em seu pai, e assim os homens se aproveitaram dessa carência afetivo-amorosa, fazendo-a acreditar que estavam em sua vida para construir a casinha da família tradicional, tão projetada em nosso imaginário. Ao final, foram cruéis, magoando-a com deslealdades, mentiras, violências psíquicas e, às vezes, físicas.

Lembro-me de um ex-namorado em particular, chamado Carlos (nome de meu pai biológico) que durante cinco anos lhe disse coisas terríveis, até que um dia, escutei do quarto em que estava o som de um forte golpe que ele lhe deu gritando, chamando-lhe de prostituta, de má mulher, palavrões típicos do machismo, etc. Esse dia, para defendê-la, peguei uma faca, e tentei feri-lo. Por sorte, um amigo seu, que presenciava a briga, interferiu segurando minha mão, impedindo que uma tragédia maior acontecesse, pelo menos, não de morte física.

No mês do incidente, minha mãe decidiu tirá-lo de nossas vidas. A partir dali, deixamos de ser o rosto da vítima acostumada à violência, que vai estragando a vida e a comunicação entre mãe e filha. Motivo esse que estamos lutando por nós, para desfazer-nos das práticas amorosas que doem. Por isso, falar e recontar são necessários no sentido de construir o caminho para o perdão.

\section{ESCUTAR-NOS SEMPRE É POSSÍVEL}

Com o intuito de lembrar, de fato, o quão importante é ouvir nossas histórias, será preciso olhar na tríade avó-mãe-filha como "ciclo de 
aprendizagens e vivências compartilhadas, em que as repetições ultrapassaram o tempo e o contexto das violências transmitidas, posto que exista uma dor grupal, um ferimento grupal” (ESTÉS, 2014, p. 413). Tal ferimento deverá ser refletido para assim desconstruí-lo, recompô-lo em outras práticas que possam curar nossos corpos esmagados, não mortos, só cheios de raivas que precisam ir embora.

As imagens fotográficas se realizam na consciência da sororidade: olhar para minha mãe, restitui meu corpo, esse corpo que olhou para a outra igualmente ferida na história cultural de meu país. Olhá-la me aproxima de seus silêncios, seus ocultamentos, constelados na intimidade de sua alma. Ademais, ela é o corpo, no qual eu nasci e para onde me voltei, para olhá-la como a mulher que ela é, e abraçar na sua nudez, sua sexualidade, como a Deusa Suja.

\section{REENCONTRANDO-NOS NA DEUSA SUJA}

Marisela sempre foi a imagem oposta ao modo puritano de minhas tias, sempre tão dedicadas ao fogão, ao lar, aos filhos (as) e ao marido. Minhas tias se esqueceram delas mesmas com o passar do tempo, porque no cotidiano as mulheres são atravessadas por muitíssimos fazeres que as esgotam. Não existem como sujeitos que necessitam cuidar de si, ter um tempo exclusivo para elas, arrumar-se, cultivar sua beleza sem a imposição do corpo moldado pela mídia.

Persiste ainda nas mulheres a ausência de conhecimento sobre sua feminidade e sexualidade. Graças à luta feminista, essas ausências vêm sendo transformadas, construindo um novo caminho para as mulheres como agentes históricos, participantes da sociedade, em suas funções políticas e culturais. Novas relações tecem outros modos de sentir, outros prazeres e pensamentos, para que nossos corpos alcancem imaginários novos, multidimensionais e, sobretudo saudáveis, em contra resposta a esse útero há tempos dominado, mercantilizado e machucado pelo patriarcado.

Nesse sentido, direciono meu olhar à Marisela, minha mamãe, a primeira mulher que conheci como feminidade, e assim liberei meus silêncios para compreender nossa história sexual e de amor; pois ainda somos seres inacabados, procurando-nos na construção de imaginários que nascem de mulheres para mulheres; desligar-nos da tradição arquetípica e representativa da ordem sexual masculina.

A prova disso é a carência de comunicação e a ignorância entre mães e pais para falar com as crianças ou adolescentes de um jeito apropriado, sem vergonhas ou tabus sobre relações sexuais. Existe, porém, o caminho obscuro que envolve sociedades latino-americanas e sul-americanas, em que a cultura industrializada e capitalizada do sexo, há muito tempo, gerou um imaginário pornográfico heteronormativo e simbólico na arte erótica dos corpos. Não temos, portanto uma pedagogia sexual assertiva, liberadora e responsável sobre ter poder de decisão sobre nossos corpos e genitais, estão mais expostos a que outros decidam por nós, e ainda mais expostos a possíveis agressores, estupradores, pederastas, pedófilos etc.

Eu e minha mãe não tivemos uma educação sexual emancipatória necessárias, o que nos pouparia de muitas lágrimas e dores. Falar do sexo livremente sem temor teria sido uma estratégia poderosa para nos defender do mundo patriarcal que explora e mercantiliza o corpo feminino.

Quanto menos formos as Musas, as Vênus, as Afrodites sexuaiscomplacentes, ou as Marias benevolentes, assexuadas e imóveis, sempre carregando, sozinhas, nos braços seus filhos; mais estaremos nos fortalecendo de um outro e próprio devir cultural-sexual-amoroso.

Nesse caso os verdadeiros arquétipos da sexualidade foram ocultos, 
as mulheres foram afastadas do conhecimento primordial, de “... um aspecto da sexualidade feminina que, nos tempos remotos era chamado de obsceno sagrado... com o significado de uma sabedoria sexual...” (ESTÉS, 2014, p. 379).

Antes de nossos úteros serem somente máquinas exploradas para reprodução sexual, havia o culto das Deusas Sujas, imagens que há muito tempo foram para as mulheres um meio de libertação e culto de seus apetites sexuais, levando consigo o cuidado da energia sexual selvagem, e, portanto sagrada, como uma comunicação natural orgânica e cósmica entre espírito, alma e corpo.

Minha mãe, eu e todas as mulheres temos esse cheiro da Deusa Suja. O que falta é ativar com paciência e meditação tais essências naturais do corpo, nas quais, a mulher erótica mora, e deixar sentir o que os cientistas chamam do feromônio. Todas nós temos, algumas em menor quantidade e outras em grande medida. Minha mãe transpira muita química, sua sensualidade atrapalha. Os homens se apaixonam por ela, e isso, às vezes, coloca-a entre a contradição de objeto e sujeito de desejo.

Em sua recente visita a Belém do Pará, após um ano de minha estadia na cidade, saímos para caminhar. Em várias situações, na rua, alguns homens falavam de sua beleza ou outros simplesmente ficavam olhando para ela. Um dia um motorista falou: Nossa, fique aqui em Belém e eu vivo com você! É claro, minha mãe, nem entendeu direito o que ele estava lhe falando, por não compreender o idioma, eu era quem traduzia para ela; e ela somente ria. Era lindo vê-la rir!

A risada entre mulheres que provêm de histórias apimentadas e sexuais são ligadas ao prazer saudável, já que nascem de experiências compartilhadas e sabedoria de mulheres para mulheres, o corpo se acorda, assim também as emoções. É isso que o riso faz, ele “.... não é unidimensional... é algo que compartilhamos com nosso próprio self bem..." (ESTÉS, 2014, p. 388), sensibiliza o encontro entre mãe e a filha no mesmo nível de empatia, de sororidade, ao reconhecer na outra a horizontalidade da sua sabedoria sexual, e uma vez mais "... o riso reorganiza, põe em ordem, reafirma a força e o poder, deixa as pessoas alegres com maior consciência do amor, elevadas pelo Eros, quando ele desfaz as tristezas e as isola da raiva..." (ESTÉS, 2014, p. 390).

Agora, falamos abertamente das relações sexuais (coisa que jamais aconteceu com a mãe dela); isso me permitiu dar um passo possível para honrar nosso corpo, o corpo dela como mulher, de maneira que sempre se deixou fotografar por mim. Sem medo de ser olhada por outros ao estar nua, deixou-me compartilhar sua imagem, e assim rompemos os silêncios e as censuras de uma geração a outra, criando a possibilidade de uma cumplicidade para mudar a vida uterina-familiar-amorosa em nós.

Por isso, até hoje, sempre falo com ela em tom de brincadeira:

- Mamãe quando você morrer, vou fazer duas filas no velório: uma para nossos familiares e amizades, e a outra vai estar lotada de todos os homens e namorados teus, que vão chorar-lhe esse dia em teu velório! - O sorriso e picardia dela, sentíamos como os pássaros, se espalhando pela casa.

\section{KATHY, ELA E EU}

Essa casa é onde ela costurou seu microcosmo de vida; seu lar é seu refúgio: onde parece sentir-se livre, sem máscaras, sem personagens. Ela esquecia no lar que houve uma outra vida. Um mistério que havia ocultado de mim por muitos anos, e só me foi falado, creio, no ano de 2016.

Esse dia, entre o café da tarde a as conversas, ela decidiu falar-me seu grande segredo, o segredo que abriu a essa outra mulher que na minha 
infância estava escondida, essa outra mulher era Kathy. (Figura $\mathrm{n}^{\circ} 4$ ).

Quem era a Kathy? Ela havia sido uma grande escolha na sua vida, e o preço para garantir a sobrevivência das duas. E quem era eu para julgá-la? Quem era eu para criar um juízo sobre sua vida? Ela havia se dado de todas as maneiras, por mim, incluindo seu corpo. Eu a olhei, forte e vulnerável; lutando sempre com unhas e dentes, como a felina defendendo a possibilidade de um porvir, e jamais se conformou ficar sem estudos, procurou obter o bacharelado e depois entre muitos vaivéns, formar-se advogada em 2001.

Sua escolha como Kathy, foi o melhor que ela podia fazer naquele tempo; era uma adolescente sem ninguém ao lado, numa cidade difícil, Caracas, vivendo e tentando que não fenecêssemos de fome. Decidir prostituirse, ser a Kathy, foi o jeito que ela viveu amargamente e aguentou por anos. Agora compreendo porque às vezes, quando criança, encontrava-a no quarto chorando. Desdobrar-se em duas pessoas não foi uma tarefa simples: uma Marisela, a estudante-mãe, e a outra a Kathy, a trabalhadora sexual.

Sei que tal escolha mudou sua perspectiva de vida e os seus relacionamentos amorosos. Ela não me conferiu esse segredo, só o expulsou de si mesma, para acabar com a autocensura que a feria; e o medo que fosse punida por mim, o grande amor da sua vida. Aquele dia, entre as migalhas do café da tarde, choramos! Abraçamos-nos muito! Nossos peitos se agitavam de tão forte emoção; beijamos nossas lágrimas. Não tínhamos nada a perdoar, não precisávamos de redenções, éramos simplesmente seres humanos; só necessitávamos seguir comunicando-nos mais uma com a outra porque, em nossas vidas, muitas coisas ruins aconteceram! Ainda estamos bem vivas e juntas, amando-nos como mãe e filha, como as mulheres que, nessa humanidade ainda vulnerável, possuem a fortaleza em reagir, mudar e enfrentar o porvir!

Nesse ínterim, meu olhar fotográfico permitiu-me "observar a transformação de alguns dos rituais da vida doméstica, desestabilizando assim os limites entre o público e o privado, e a criação de um novo valor social" (HERNÁNDEZ, 2011, p. 146). Procuro então, esse outro valor de resistência que fornece meu papel como produtora simbólica, na criação de imagens que nasceram como falei anteriormente, das experiências de vida de mulheres que interagem na sua "dimensão ontológica existencial" (CABRAL, 2013, p.149) e, que dentro de uma rede de relações de poder determinaram, até certo ponto, as ações e reações na vida.

Vê-la através da câmara é lembrar a mulher que conquista um tempo para cuidar do corpo, tomar banhos de cheiro para ativar a energia; convidandome a dançar com o cheiro da vida (Figuras $\mathrm{n}^{\circ} 5$ e $\mathrm{n}^{\circ} 6$ ). Por este motivo, tomei esse espaço de feiticeira, invocando as deusas e as santas que moram em nós e nos fazem acreditar na ativação energética e na proteção do amor. Porque o amor salva, o amor cura!

As fotografias digitais, produzidas com a câmera Nikon D3100 e celular, são uma experiência com a luz ambiente e com o instante, sem a preparação prévia de cenas. Os desfoques, o flou e o grão forte nas imagens são intencionais, na construção de um olhar que foi desfiando os silêncios, sempre no momento em que estávamos nuas, que era o ritual que fazíamos ao chegar a casa, onde nos despojávamos daquilo que estava lá fora.

As imagens selecionadas, que compõem este ensaio-relato, são partes de muitas fotografias captadas em diferentes anos de convivência com minha mãe; no percurso de uma vida e da comunicação entre nós, em nossos próprios tempos e ritmos. E minha mãe é a imagem sempre em movimento, flutuante, como seu signo, gêmeos; às vezes perto, outras vezes, bem distante.

A prática do nu fotográfico me permitiu construir um olhar sobre seu corpo, sem procurar estéticas ou estilos estabelecidos. Ao atuar na cumplicidade dessa vida considerada "privada", minha mãe deixou-se fotografar desnuda, e assim poderá "ser, então, consumida de maneira pública" (HERNÁNDEZ, 2011, p. 146). Estar agora em frente à câmera é estar em forma de imagem, VOL. 15 |N.2 | DEZ. 2018 
REVISTA DO PROGRAMA DE PÓS-GRADUAÇÃO EM COMUNICAÇÃO, LINGUAGENS E CULTURA DA UNIVERSIDADE DA AMAZÔNIA

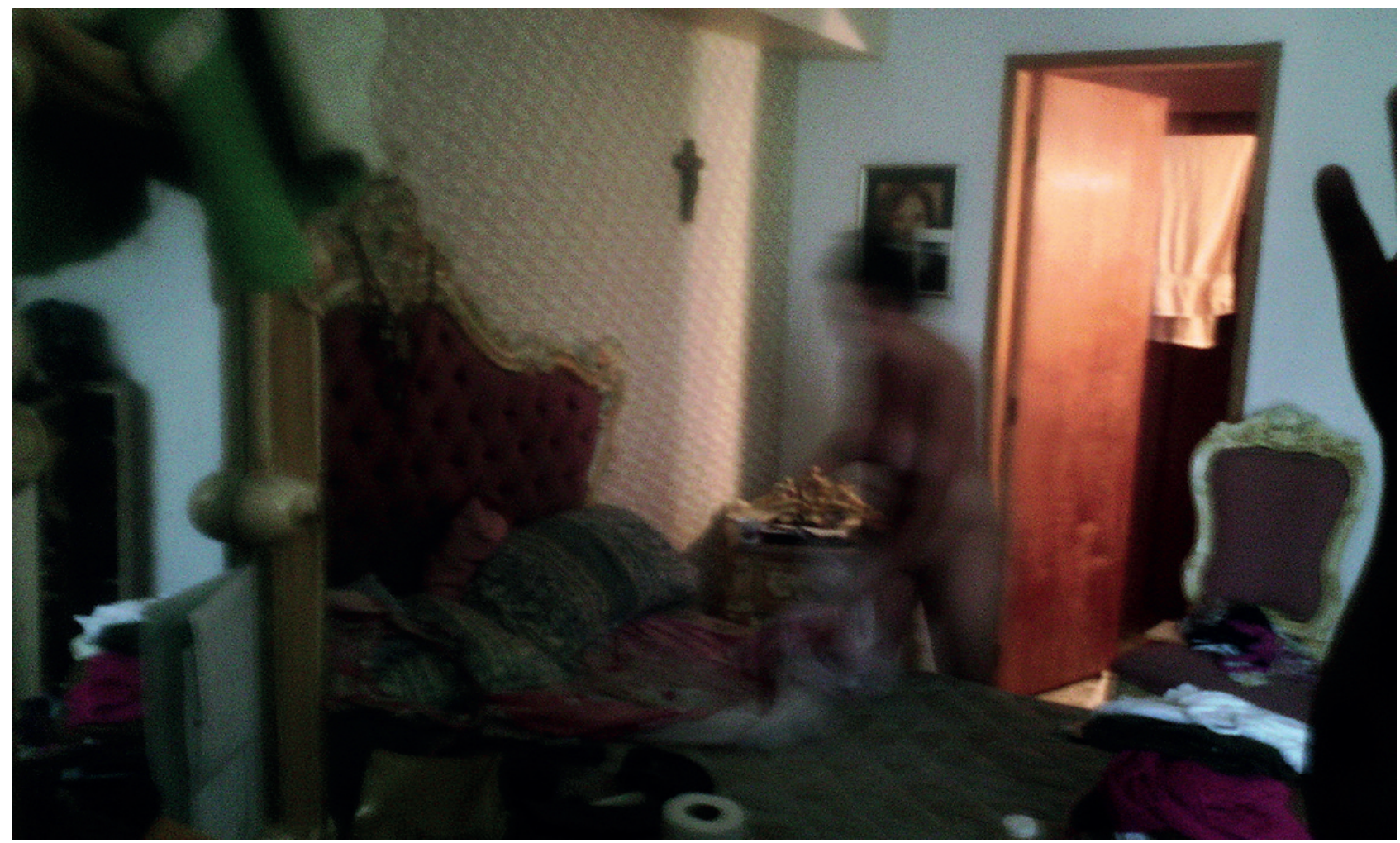

Figura $n^{\circ} 5$.

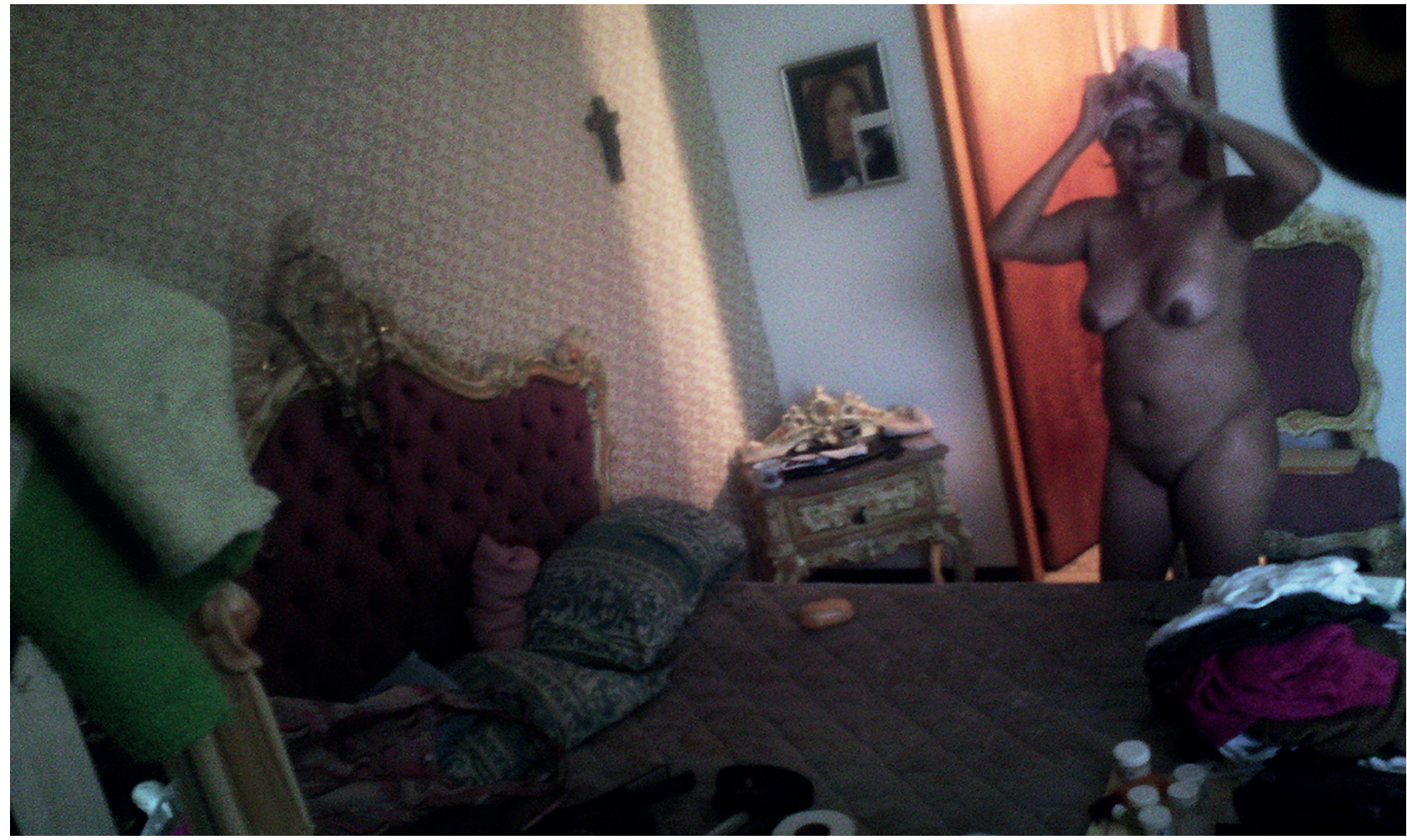

Figura $n^{\circ} 6$. 
construída pelo meu olhar, mas também como corpo para ser olhado como signo artístico. Como prática artística, torna-se ação pública, ao ligar-se às relações afetivas e socioculturais de quem olha, e ao mesmo tempo aproximarme de um olhar, de uma perspectiva entre mulheres.

\section{REFERÊNCIAS}

CABRAL, Blanca Elisa. Sexo, poder y género I-II. Caracas: El Perro y la Rana, 2013

CARRERA, Felipe. El comportamiento sexual del venezolano. Caracas: Monte Ávila, 1978.

DUSSEL, Enrique. Para una Erótica Latinoamericana, Venezuela: el Perro y la Rana. 2013.

HERNÁNDEZ, Carmen. Insubordinación. In: Diana Eltit y Paz Errazuriz. Urgencia y emergencia de una postura artística en la Chile postgolpe (1983-1994). Venezuela: Monte Ávila Editores Latinoamericana, 2011.

ESTÉS, Clarissa. Mujeres que corren con los Lobos. España: Zeta Bolsillo, 2014.

\section{LISTA DE IMAGENS}

Figura $\mathrm{n}^{\circ} 1$. Na tua ausência, papai. Fotografia digital da autora.

Figura $\mathrm{n}^{\circ}$ 2. A Marisela. Fotografia digital da autora. Caracas-Venezuela, 2014.

Figura $n^{\circ} 3$. A Marisela e Ela. Fotografia digital da autora. Caracas-Venezuela, 2014.

Figura ${ }^{\circ} 4$. A Marisela, a Kathy e minha mamãe. Fotografia digital da autora.

Figura $\mathrm{n}^{\circ}$ 5. Ela e eu (1). Fotografia digital da autora. Caracas-Venezuela, 2016.

Figura ${ }^{\circ}$ 6. Ela e eu (2). Fotografia digital da autora. Caracas-Venezuela, 2016.

Recebido em 04 Nov 2018 | Aprovado em 03 Dez 2018

Maryori Katherine Cabrita GARCIA

Mestranda em Artes no Programa de Pós-graduação em Artes (Ppgartes) pela Universidade Federal do Pará (UFPA), Licenciada em Artes Plásticas pela Universidade Experimental Nacional das Artes (UNEARTE) (Venezuela) Bacharel em Artes Visuais na Escola de Artes Visuais Cristóbal Rojas (Venezuela) Profesora de fotografia da UNEARTE (Venezuela) Bolsista CAPES. E-mail: obituario1983@gmail.com.

Ana Cláudia do Amaral LẼ̃O (orientadora)

Artista e pesquisadora. Doutora em Comunicação e Semiótica pela Pontifícia Universidade Católica de São Paulo. Professor Adjunto II do Instituto de Ciências da Arte da Universidade Federal do Pará. Líder do grupo de Pesquisa Lab AMPE. Coordenadora da Pesquisa "Sobre pele, o rio: a paisagem no território da Cultura atravessando o Campo da Arte" e do projeto de Extensão "Registro Permeáveis: falas de artistas para cadernos e escrituras e diálogos entre Arte e Política na Amazônia".E-mail: aclaudialeao@gmail.com. 